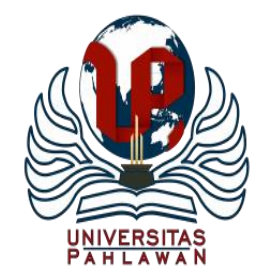

Jurnal Basicedu Volume 4 Nomor 4 Tahun 2020 Halm. 784 - 793

JURNAL BASICEDU

Research \& Learning in Elementary Education

https://jbasic.org/index.php/basicedu/index

\title{
Peningkatan Keterampilan Berpikir Kreatif Dan Kritis Siswa Menggunakan Metode Discovery Learning di Sekolah Dasar
}

\author{
Septiana Aisyiah $^{1}$, Taufina ${ }^{2,}$ Maria Montessori ${ }^{3}$ \\ Universitas Negeri Padang, Sumatera Barat, Indonesia ${ }^{1,2,3}$ \\ E-mail: septianaaisyiah@gmail.com ${ }^{1}$, taufina_taufik@yahoo.co.id ${ }^{2}, \underline{\text { mariamontesori@ fis.unp.ac.id }}$
}

\begin{abstract}
Abstrak
Tujuan dari penelitian ini adalah untuk meningkatkan keterampilan berpikir kreatif and kritis siswa dalam pembelajaran IPS dengan mengunakan metode Discovery Learning di kelas IV sekolah dasar. Jenis penelitian ini adalah Penelitian Tindakan Kelas dengan menggunakan pendekatan kualitatif and kuantitatif. Subjek penelitian ini adalah siswa kelas IV sebanyak 30 orang yang terdiri dari 13 pria dan 17 wanita. Penelitian ini dilaksanakan dalam dua siklus dengan prosedur penelitian yang terdiri dari perencanaan, pelaksanaan, observasi, and refleksi. Hasil penelitian menunjukkan peningkatan dalam hal a) RPP Siklus I adalah 76,79\% dan Siklus II 96\%, b) Implementasi pada aspek guru pada siklus pertama adalah 80\% dan siklus kedua adalah 95\% sedangkan implementasi pada aspek siswa pada siklus I adalah 75\% dan siklus II 95\%, c) Keterampilan berpikir kreatif and kritis siswa pada siklus I adalah 75,89\% dan siklus kedua adalah $75,89 \%$. Penelitian ini menyimpulkan bahwa dengan menggunakan metode Discovery Learning, keterampilan berpikir kratif dan kritis siswa kelas IV hingga 44 KLB Kota Padang meningkat.
\end{abstract}

Kata kunci: Keterampilan berpikir kreatif, Keterampilan berpikir kritis, Metode discover learning

Abstract

The purpose of this study is to improve students' creative and critical thinking skills in social studies learning by using the Discovery Learning method in grade IV elementary school. This type of research is Classroom Action Research using qualitative and quantitative approaches. The subjects of this research were grade IV students as many as 30 people consisting of 13 men and 17 women. The research was conducted in two cycles with research procedures consisting of planning, implementation, observation, and reflection. The results showed an increase in terms of a) RPP Cycle I was 76.79\%\% and Cycle II 96\%, b) The implementation in the aspect of the teacher in the first cycle was $80 \%$ and the second cycle was $95 \%$ while the implementation in the aspect of students in the first cycle was $75 \%$ and second cycle 95\%, c) Creative and critical thinking skills of students in the first cycle is $75.89 \%$ and the second cycle is $75.89 \%$. This research concludes that by using the Discovery Learning method, the creative and critical thinking skills of grade IV students up to 44 KLB Paandg City increase.

Keywords: creative thinking skill, critis thinking skill, discovery learning

Copyright (c) 2020 Septiana Aisyiah,Taufina, 'Maria Montessori

$\triangle$ Corresponding author :

Address : Air Tawar Padang

ISSN 2580-3735 (Media Cetak)

Email : septianaaisyiah@gmail.com

ISSN 2580-1147 (Media Online)

Phone : 08137464264

DOI: $10.31004 /$ basicedu.v4i4.454 


\section{PENDAHULUAN}

Salah satu keterampilan yang dapat meningkatkan kesuksesan seseorang adalah keetrampilan berpikir kratif dan kritis dalam menyelesaikan sebuah masalah yang dihadapinya dalam kehidupannya (Marzuki, Asih, \& Wahyudin, 2019). Keluarga adalah faktor yang berpengaruh terhadap peningkatan keterampilan berpikir kratif dan kritis pada seorang siswa (Jankowska \& Karwowski, 2019).

Keterampilan ini pada siswa sudah di dalam diri mereka masing-masing, namun semua itu dipengaruhi oleh lingkungan keluarga dan masyarakat. Keterampilan berpikir kratif dan kritis yng tinggi dapat membuat seorang siswa menyelesaikan masalahnya dengan menilai masalah tersebut dan cara mengatasinya.

Keterampilan ini pada siswa dapat juga dibuktikan pada saat dia mengatasi masalah yang tidak hanya di rumah namun juga di sekolah, seperti dalam mengatasi masalah dalam pembelajaran yng dipelajarinya. Keterampilan berpikir kreatif dan kritis siswa tersebut dalam pembelajaran akan berdampak untuk mengatasi masalah revolusi informasi di dalam pendidikan (Ahmed Soliman, 2019).

Pada kurikulum 2013 siswa harus punya keterampilan abad 21, yaitu berpikir tingkat tinggi seperti kreatif berpikir, dapat memecahkan masalah, komunikasi, perpaduan, mencipta dan berbagi informasi (Wijayati, Sumarni, \& Supanti, 2019). Keterampilan berpikir kratif dan kritis dalam pembelajaran bertujuan agar siswa dapat sukses pada saat ini dan masa depannya (Lucas, 2019).
Kesuksesan yng didapatkan siswa tersebut dalam pembelajaran tidak lepas dari siswa tersebut harus memiliki keterampilan ini, karena dengan perkembangan teknologi saat ini dan akan terus maju untuk masa depan, itu terjadi tidak hanya di lingkungan siswa saja tapi juga di seluruh dunia (Ulger, 2018). Jadi dapat dikatakan kalau seorang siswa agar dapat mengahadapi kemajuan teknologi dan masalah yng dihadapinya dalam kehidupan sehari-harinya maka siswa tersebut harus memiliki kemampuan keterampilan berpikir kratif dan kritis.

Keterampilan tersebut akan terlaksana pada saat siswa mengalami beberapa langkah, yaitu adanya pertanyaan, informasi yang akan dicerna, pertimbangan informasi tersebut, mengungkapkan hal-hal yng baru dengan berbagai pertimbangan (Rohaeti, Ramaand, \& Fitriani, 2019).

Langkah-langkah tersebut terlaksana saat seorang siswa dalam pembelajaran. Penyelesaian masalah dalam pembelajaran dengan keterampilan berpikir kratif dan kritis dapat menyelesaikan masalah tersebut dengan ide-ide yang baru dengan mempertimbangkan beberapa informasi (Zubaidah, Fuad, Mahanal, \& Suarsini, 2017).

Ciri-ciri dari keterampilan ini adalah lancar dalam menganalisa masalah, mengusulkan pendapat dengan terbuka, ide-ide yang baru, dan mengatur semua itu menjadi pemecahan masalah (Babic, Lackovic, \& Matejic, 2019). Jadi keterampilan berpikir kratif dan kritis ini akan menghasilkan hal-hal yang baru dengan adanya masalah yang ada (Hoicka et al., 2016). Keterampilan ini dalam pembelajaran dapat membantu siswa dan guru untuk menghasilkan hal-hal yang baru dalam menyelesaikan masalah 
yang mereka hadapi (Ahmed Soliman, 2019). Kegiatan pembelajaran ini adalah kegiatan ikatan antara guru dan sisiwa di sekolah untuk menentukan keberhasilan dan kesuksesan seorang siswa dalam proses pembelajaran.

Pembelajaran IPS ialah salah satu mata pelajaran yang diajarkan berawal dari SD. IPS berperan dalam memfungsionalkan dan merealisasikan ilmu-ilmu sosial yang bersifat teori ke dalam kehidupan nyata yang ada dan berkembang di masyrakat. Menurut Isjoni (2007:21) menyatakan bahwa IPS ialah suatu program pendidikan yang secara keseluruhan mempersoalkan manusia antara lingkungan fisik dengan lingkungan sosialnya. Melalui IPS, siswa dibentuk menjadi masyarakat yang baik dan demokratis serta dapat berpartisipasi dan berperan aktif dalam mengatasi masalah dalam hidup masyarakat.

Tujuan pembelajaran IPS adalah untuk mendidik dan memberi bekal kepada siswa dalam mengenal konsep-konsep yang berkaitan dengan lingkungan masyarakat dan sekitarnya yang dapat menciptakan warga negara yang demokratis, berfikir kritis dan logis dalam memecahkan suatu permasalahan sosial. Maka dari itu, guru diharapkan mampu untuk mengenalkan konsepkonsep yang berhubungan dengan kehidupan masyarakat dan lingkungan yang ada di sekitar siswa serta mengajarkan siswa untuk mengasah kemampuan dasar yang dimilikinya dengan mengunakan cara atau teknik penyampaian materi yang menarik sehingga pembelajaran tidak menjadi membosankan tetapi menyenangkan bagi siswa. Selain itu, guru juga memberikan kebebasan bagi siswa dalam beraktivitas dan bertindak sebagai fasilitator untuk menciptakan pembelajaran yang aktif, inovatif, kreatif, efektif dan menyenangkan (PAIKEM).

Berdasarkn hasil observasi yang peneliti lakukan di Kelas IV SDN 44 Kalumbuk Kec Kuranji Kota Padang, peneliti melihat dalam pelaksanaan pembelajaran IPS kemampuan siswa dalam merumuskan suatu masalah masih kurang, keaktifan siswa dalam proses pembelajaran masih kurang, motivasi dan minat siswa dalam belajar masih kurang sehingga pembelajaran menjadi kurang bersemangat, kemampuan kerja sama siswa dalam melakukan tugas kelompok masih rendah, dan kemampuan siswa dalam memecahkan masalah masih rendah. Keterampilan berpikir kreatif dan kritis siswa juga kurang dalam pembelajaran.

Akibat dari permasalahan yang ditemukan dalam pembelajaran IPS menyebabkan pada hasil belajar siswa yang masih rendah jika diukur dari kriteria ketuntasan minimum (KKM) yang telah ditentukan. Oleh karena itu, untuk tercapainya pembelajaran IPS yang diharapkan, maka guru dapat meningkatkan keterampilan berpikir kratif dan kritis siswa dengan menggunakan metode pembelajaran yang bervariasi.

Salah satu metode pembelajaran yang dapat digunakan ialah dengan menggunakan metode Discovery Learning. Menurut Hosnan (Sani, 2013) "Discovery Learning adalah pembelajaran yang mengunakan masalah nyata (autentik) yang tidak terstruktur dan bersifat terbuka sebagai konteks bagi siswa untuk mengembangkan keterampilan menyelesaikan masalah dan berpikir kritis, kreatif 
serta sekaligus membangun pengetahuan baru. Metode pembelajaran Discovery Learning yaitu model pembelajaran yang dapat mengembangkan siswa untuk berpikir kritis dan kreatif dalam memecahkan suatu masalah, aktif dan bekerja sama dalam sebuah kelompok, serta siswa bebas dalam mengemukakan idenya bersama teman yang lain dengan mengaitkan pengalaman kehidupan nyata siswa dengan materi tersebut.

Berdasarkan latar belakang masalah yang telah dikemukakan di atas, maka rumusan masalah secara umum dalam penelitian ini adalah "Bagaimana Peningkatan Keteramplan Kreatif dan Kritis Siswa dalam Pembelajaran IPS dengan Mengunakan Metode Discovery Learning di Kelas IV SDN 44 Kalumbuk Kec Kuranji Kota Padang. Sedangkan rumusan masalah secara khusus adalah mendeskripsikan bagaimana rencana pelaksanaan pembelajaran, pelaksanaan pembelajaran, dan peningkatan keterampilan berpikir kreatif dan kritis siswa dalam pembelajaran IPS.

\section{METODE}

Penelitian ini adalah Penelitian Tindakan Kelas (PTK) dengan mengunakan pendekatan kualitatif dan kuantitatif. Pendekatan kualitatif merupakan pendekatan yang mengungkapkan kenyataan yang diperoleh peneliti dengan langsung di lapangan dengan mendeskripsikan dalam bentuk kata-kata terhadap apa yang terjadi oleh subjek penelitian. Sedangkan pendekatan kuantitatif merupakan pendekatan yang datanya disajikan dalam bentuk angka untuk mendeskripsikan subjek penelitian.
Penelitian dilakukan yang terdiri dari dua siklus. Siklus I terdiri dari 2 kali pertemuan dan Siklus II terdiri dari 1 kali pertemuan. Menurut pendapat Kemmis dan M.CTaggar (dalam Uno, 2011:88) model siklus yang digunakan dalam penelitian tindakan kelas terdiri dari 4 tahapan yaitu perencanan, pelaksanan, pengamatan dan refleksi.

Penelitian ini dilaksanakan di kelas IV SDN 44 Kalumbuk Kec Kuranji Kota Padang pada semester genap tahun ajaran 2017/2018. Subjek dalam penelitian ini ialah siswa kelas IV SDN 44 Kalumbuk Kec Kuranji yang berjumlah sebanyak 30 orang yang terdiri dari 13 orang laki-laki dan 17 orang perempuan.

Pada penelitian ini data dikumpulkan dengan menggunakan cara observasi dan tes. Data yang dikumpulkan berupa a) RPP yang dirancang guru sebelum mengajar, b) Pengamatan pelaksanaan pembelajaran terhadap aspek guru dan aspek siswa, c) Hasil belajar siswa. Sumber data penelitian adalah guru dan siswa kelas IV SDN 44 Kalumbuk Kec Kuranji Kota Padang.

\section{HASIL DAN PEMBAHASAN}

Penelitian dilakukan dengan empat tahapan yaitu perencanan, pelaksanan, pengamatan, dan refleksi. Penelitian siklus I dilakukan sebanyak 2 kali pertemuan pada hari Kamis tanggal 5 April 2018 and 12 April 2018 pukul 07.30-09.20 WIB dengan alokasi waktu $3 \times 35$ menit per pertemuan.

Perencanaan pembelajaran disusun berdasarkan langkah metode Discovery Learning pada semester II dengan berpedoman pada K13 yang dituangkan dalam bentuk RPP. Peneliti 
berkolaborasi bersama guru kelas IV SDN 44 Kalumbuk Kec Kuranji Kota Padang untuk menganalisis Rencana Pelaksanaan Pembelajaran yang berupa standar kompetensi, kompetensi dasar, indikator pembelajaran, dan tujuan pembelajaran yang akan dikembangkan. Materi pembelajaran yang dibahas pada siklus I pertemuan 1 adalah kegiatan ekonomi tentang pekerjaan I pertemuan 2 adalah pekerjaan di tempat tinggal. Sebelum pelaksanan pembelajaran berlangsung, adapun yang peneliti siapkan terlebih dahulu yaitu rencana pelaksanaan pembelajaran (RPP), lembar diskusi kelompok (LDK), lembar evaluasi, lembar penilaian afektif (skalasikap) dan kertas HVS yang digunakan siswa untuk membuat peta konsep serta kunci jawaban yang digunakan dalam pembelajaran.

Pelaksanan pembelajaran pada siklus I melalui 3 kegiatan pembelajaran yaitu dimulai dari kegiatan awal, inti, dan akhir. Kegiatan awal diawali dengan mengucapkan salam dan mengkondisikan kelas untuk memulai proses pembelajaran. Kemudian peneliti meminta siswa untuk berdoa dan dilanjutkan dengan menyampaikan appersepsi dan tujuan pembelajaran.

Kegiatan inti langkah 1 menjelaskan tujuan pembelajaran berupa materi pembelajaran. Langkah 2 membegi petunjuk percobaan. Selanjutnya siswa duduk berkelompok sesuai yang telah ditetapkan dan guru membagikan LDK kepada setiap kelompok serta memberikan penjelasan tentang petunjuk cara pengisian LDK. Langkah 3 siswa melaksanakan percobaan dengan bimbingan guru. Langkah 4 siswa menujukkan gejala yng diamati seperti dalam pelaksanaan percobaan. Langkah 5 menyimpulkan hasil percobaaan, guru memberikan penguatan pada siswa dan meminta siswa untuk melaporkan hasil percobaan ke depan kelas degan perwakilan kelompok. Kegiatan akhir, guru bersama siswa menyimpulkan pembelajaran kemudian dilanjutkan dengan melakukan evaluasi dan mengisi lembar penilaian skala sikap. Setelah itu pembelajaran ditutup dengan berdoa.

Pengamatan dilakukan terhadap hasil penyusunan Rencana Pelaksanaan Pembelajaran (RPP), aspek guru dan aspek siswa. Pengamatan penilaian pada RPP pada siklus I adalah dengan rata-rata $76,79 \%$ sedangkan untuk aspek guru adalah dengan rata-rata $80 \%$ dan untuk aspek siswa dengan rata-rata $75 \%$.

Untuk melakukan penilaian keterampilan kreatif dan kritis siswa dalam pembelajaran IPS terdiri dari ranah kognitif, afektif dan psikomotor. Hasil siswa pada siklus I dalam aspek kognitif nilai yang diperoleh ialah dengan rata-rata $75 \%$, untuk aspek afektif nilai yang diperoleh ialah dengan rata-rata 58,35\% sedangkan untuk aspek psikomotor nilai yang diperoleh ialah dengan ratarata $58,36 \%$. Secara keseluruhan nilai yang diperoleh untuk keterampilan kratif dan kritis siswa pada siklus I ialah dengan rata-rata $33,5 \%$ dengan kriteria kurang.

Berdasarkan hasil observasi dan tes yang telah dilakukan maka dapat disimpulkan bahwa keterampilan berpikir kreatif dan kritis siswa belum mencapai kriteria keberhasilan yang diinginkan dan kriteria ketuntasan minimum yang telah ditetapkan. Dengan demikian, peningkatan 
hasil belajar siswa dalam pembelajaran IPS akan peneliti lanjutkan pada siklus II dengan lebih baik sesuai dengan rancangan RPP dengan mengunakan metode Discovery Learning.

Pada siklus 2, penelitian dilakukan dengan empat tahapan yaitu perencanan, pelaksanan, pengamatan, dan refleksi. Penelitian siklus II dilakukan sebanyak 1 kali pertemuan pada hari Kamis tanggal 26 April 2018 pukul 07.30-09.20 WIB dengan alokasi waktu 3x35 menit per pertemuan.

Perencanaan pembelajaran disusun berdasarkan langkah metode Discovery Learning pada semester II dengan berpedoman pada K13 yang dituangkan dalam bentuk RPP. Peneliti berkolaborasi bersama guru kelas IV SDN 44 Kalumbuk Kec Kuranji Kota Padang untuk menganalisis Rencana Pelaksanaan Pemblajran yang berupa standar kompetensi, kompetensi dasar, indikator pembelajaran, dan tujuan pembelajaran yang akan dikembangkan. Materi pembelajaran yang dibahas pada siklus II pertemuan 1 adalah pekerjaan yang ada di Indonesia. Sebelum pelaksanaan pembelajaran berlangsung, adapun yang peneliti siapkan terlebih dahulu yaitu rencana pelaksanaan pembelajaran (RPP), lembar diskusi kelompok (LDK), lembar evaluasi, lembar penilaian afektif (skala sikap) dan kertas HVS yang digunakan siswa untuk hasil diskusi serta kunci jawaban yang digunakan dalam pembelajaran.

Pelaksanan pembelajaran pada siklus II melalui 3 kegiatan pembelajaran yaitu dimulai dari kegiatan awal, inti, dan akhir. Kegiatan awal diawali dengan mengucapkan salam dan mengkondisikan kelas untuk memulai proses pembelajaran. Kemudian peneliti meminta siswa untuk berdoa dan dilanjutkan dengan menyampaikan appersepsi dan tujuan pembelajaran.

Kegiatan inti langkah 1 menjelaskan tujuan pembelajaran berupa materi pembelajaran. Langkah 2 memberi petunjuk percobaan. Selanjutnya siswa duduk berkelompok sesuai yang telah ditetapkan dan guru membagikan LDK kepada setiap kelompok serta memberikan penjelasan tentang petunjuk cara pengisian LDK. Langkah 3 siswa melaksanakan percobaan dengan bimbingan guru. Langkah 4 siswa menujukkan gejala yang diamti seperti dalam pelaksanaan percoban. Langkah 5 menyimpulkan hasil percobaan, guru memberikan penguatan pada siswa dan meminta siswa untuk melaporkan hasil percobaan ke depan kelas degan perwakilan kelompok. Kegiatan akhir, guru bersama siswa menyimpulkan pembelajaran kemudian dilanjutkan dengan melakukan evaluasi dan mengisi lembar penilaian skala sikap. Setelah itu pembelajaran ditutup dengan berdoa.

Pengamatan dilakukan terhadap hasil penyusunan Rencana Pelaksanaan Pembelajaran (RPP), aspek guru dan aspek siswa. Pengamatan penilaian pada Rencana Pelaksanaan Pembelajaran (RPP) pada siklus II adalah dengan rata-rata 90\% sedangkan untuk aspek guru adalah dengan ratarata 95\% dan untuk aspek siswa dengan rata-rata $90 \%$.

Penilaian hasil belajar siswa dalam pembelajaran IPS terdiri dari ranah kognitif, afektif dan psikomotor. Hasil belajar siswa pada 
siklus II dalam aspek kognitif rata-rata yang diperoleh yaitu $86 \%$, untuk aspek afektif rata-rata yang diperoleh yaitu 91,67\%, sedangkan untuk aspek psikomotor rata-rata yang diperoleh yaitu $87,20 \%$. Secara keseluruhan nilai yang diperoleh untuk hasil belajar siswa pada siklus II ialah dengan rata-rata $88,29 \%$ dengan kriteria sangat baik.

Berdasarkan hasil observasi dan tes yang telah dilakukan maka dapat disimpulkan bahwa keterampilan berpikir kreatif dan kritis siswa sudah mencapai kriteria keberhasilan yang diinginkan dan kriteria ketuntasan minimum yang telah ditetapkan. Dengan demikian, peningkatan hasil belajar siswa dalam pembelajaran IPS dengan menggunakan metode Discovery Learning di kelas IV SDN 44 Kalumbuk Kec Kuranji Kota Padang sudah berhasil.

Berdasarkan hasil penlitian pelaksanan pembelajaran IPS dengan menggunakan metode Discovery Learning pada siklus I ini mengacu pada materi mengenal kegiatan ekonomi di daerahnya. Sebelum melaksanakan proses pembelajaran guru terlebih dahulu membuat rancangan pembelajaran dalam bentuk RPP. RPP pada siklus I disajikan dalam $2 x$ pertemuan dengan waktu pelaksanaan selama $3 \times 35$ menit setiap pertemuannya.

Berdasarkan catatan hasil penelitian pada siklus I peneliti menemukan beberapa kekurangan ialah: 1) menjelaskan tujuan pembelajaran pada keadaan ini saat guru menyampaikan tujuan pembelajaran siswa masih banyak yang tidak mendengarkan dan tidak fokus, 2) membagi petunjuk percobaan, di situasi ini siswa masih paham dengan petunjuk percobaan yang dibagikan, 3) siswa melaksanakan percobaan dengan bimbingan guru, siswa masih banyak yang melakukan percobaan secara individu tidak kelompok, 4) siswa menunjukkan gejala yang diamati, saat percobaan siswa masih banyak yang mengobrol dan berbicara, 5) siswa menyimpulkan hasil percobaan, pada kegiatan ini hasil percobaan tersebut masih jauh dari yang diharapkan. Pelaksanaaan percobaan belum nampak keterampilan berpikir kreatif dan kritis siswa. Menurut Majid (2014:144) yang menyatakan bahwa RPP ialah suatu rencana yang menggambarkan prosedur dan pengorganisasian dalam pembelajaran agar tercapainya satu KD yang telah ditetapkan dalam standar isi dan dijabarkan melalui silabus.

Berdasarkan perencanaan yang telah disusun, pelaksanaan pembelajaran dilaksanakan sesuai dengan yang telah direncanakan. Pada siklus I dilakukan dalam 2x pertemuan dengan waktu pelaksanaan 3x35 menit setiap pertemuannya.

Berdasarkan diskusi peneliti dengan guru kelas IV SDN 44 Kalumbuk Kec Kuranji Kota Padang ditemukan beberapa hal yaitu: 1) menjelaskan tujuan pmbelajaran pada keadaan ini saat guru menyampaikan tujuan pembelajaran belum mudah dipahami siwa, 2) membagi petunjuk percobaan, di situasi ini guru hanya membagikan petunjuk percobaan tanpa penjelasan, 3) siswa melaksanakan percobaan dengan bimbingan guru, guru tidak mengontrol kegiatan percobaan siswa, 4) siswa menunjukkan gejala yang diamati, saat percobaan tidak dibimbing 
guru-guru masih diam di tempat duduk sambil mengamati dari jauh, 5) siswa menyimpulkan hasil percobaan, pada kegiatan ini hasil percobaan tersebut masih jauh dari yang diharapkan. Tindakan guru yang belum tepat sehingga keterampilan berpikir kreatif dan kritis siswa tidak dapat berkembang dengan baik dalam pembelajaran.

\section{Keterampilan Berpikir Kreatif dan Kritis Siklus I}

Berdasarkan catatan pada lembar observasi dan diskusi peneliti dengan observer penyebab belum tercapainya hasil belajar secara maksimal pada siklus I adalah siswa masih banyak belum aktif dalam proses pembelajaran serta alokasi waktu yang masih kurang dimanfaatkan sebaik mungkin. Setelah diperhatikan data hasil penelitian yang berkaitan dengan evaluasi pembelajaran, nilai yang diperoleh siswa masih dibawah kriteria ketuntasan belajar yang diinginkan.

Dari analisis penlitian siklus I, persentase rata-rata yang diperoleh pada evaluasi aspek kognitif siklus I pertemuan 1 yaitu $70 \%$ dan persntase rata-rata yang diperoleh pada evaluasi aspek kognitif siklus 1 pertemuan 2 yaitu $80 \%$. Pada aspek afektif persentase rata-rata yang diperoleh pada siklus I pertemuan 1 adalah 50\% dan persentase rata-rata yang diperoleh pada aspek afektif siklus I pertemuan 2 adalah $66,67 \%$. Sedangkan untuk aspek psikomotor persentase rata-rata yang diperoleh pada siklus I pertemuan 1 adalah $41,67 \%$ dan nilai rata-rata yang diperoleh pada aspek psikomotor siklus I pertemuan 2 adalah $75 \%$.
Berdasarkan hasil analisis persentase yang dilakukan pada aspek kognitif, afektif dan psikomotor terhadap keterampilan berpikir kreatif dan kritis siswa pada siklus I nilai rata-rata yang diperoleh adalah $21 \%$ dengan 34 orang anak yang belum mencapai hasil yang diharapkan.

Berdasarkan paparan hasil data pengamatan hasil belajar siswa pada siklus I, maka direncanakan untuk dapat melakukan perbaikan pada pembelajaran IPS berikutnya pada siklus II. Perbaikan-perbaikan tindakan pada siklus II dapat dilakukan dengan mengupayakan peningkatan pemahaman siswa (kognitif) terhadap materi yang diberikan dengan cara memperluas cakupan materi yang diajarkan. Selain itu, upaya perbaikan dalam peningkatan hasil belajar siswa pada aspek afektif dapat dilakukan agar siswa lebih mengaplikasikannya dalam kehidupan sehari-hari seperti halnya juga dengan aspek psikomotor.

Pada siklus 2, Perencanaan pembelajaran pada siklus II tidak jauh berbeda dengan siklus I. Berdasarkan hasil pengamatan perencanaan pembelajaran pada siklus II mendapatkan kualifikasi sangat baik (SB) karena ada beberapa aspek yang mengalami peningkatan seperti pada aspek pemilihan materi ajar telah sesuai dengan tujuan pembelajaran dan karakteristik siswa, pada aspek teknik pembelajaran telah sesuai dengan karakteristik siswa, dan pada aspek kelengkapan instrumen soal sudah disertai dengan pedoman penskoran yang lengkap. Hasil penilaian Rencana Pelaksanaan Pemblajran (RPP) pada siklus II diperoleh dengan nilai 90\% dengan kualifikasi sangat baik (SB). Menurut Muslich (2009:53) menyatakan bahwa Rencana Pelaksanaan 
Pembelajaran ialah suatu rancangan pembelajaran yang disusun perunit mata pelajaran yang ditetapkan guru untuk mengajar dalam pembelajaran di kelas".

Berdasarkan pemaparan data diatas, dapat disimpulkan bahwa perencanaan pembelajaran IPS dengan mengunakan metode Discovery Learning telah terlaksana dengan kualifikasi sangat baik (SB) pada siklus II.

Berdasarkan perencanan yang telah disusun, pelaksanan pembelajaran dilakukan sesuai dengan apa yang telah direncanakan yang disajikan dalam $1 \mathrm{x}$ pertemuan. Pelaksanan pembelajaran pada siklus II sudah terlaksana dengan baik, tetapi masih ada beberapa deskriptor yang belum muncul seperti guru belum membimbing siswa dalam percobaan dengan menggunakan bahasa yang mudah dipahami siswa dan menyimpulkan pembelajaran yang telah dipelajari.

Berdasarkan hasil pengamatan penelitian pada siklus II dapat dilihat hasil penilaian pada aspek guru adalah 95\% dan untuk hasil penilaian pada aspek siswa adalah 90\% dengan kualifikasi sangat baik (SB).

\section{Keterampilan Berpikir Kreatif dan Kritis Siklus II}

Berdasarkan hasil belajar siswa yang diperoleh setelah melakukan evaluasi jika dilihat dari segi aspek kognitif pada siklus II adalah 86\% dengan kualifikasi sangat baik (SB), aspek afektif pada siklus II adalah 91,67\% dengan kualifikasi sangat baik (SB), dan aspek psikomotor pada siklus II adalah 83,33\% dengan kualifikasi sangat baik (SB). Dilihat berdasarkan kualifikasi keberhasilan belajar sebanyak 30 anak, terdapat 28 orang yang mencapai kriteria ketuntasan (90\%) and 2 orang yang belum mencapai kriteria ketuntasan (10\%).

Berdasarkan perencanaan dan proses pelaksanaan pembelajaran yang diperoleh pada siklus II, maka pelaksanan pembelajaran pada siklus II telah terlaksana dengan sangat baik dan peneliti telah berhasil dalam meningkatkan hasil belajar siswa dalam pembelajaran IPS dengan menggunakan metode Discovery Learning di kelas IV SDN 44 Kalumbuk Kec Kuranji Kota Padang.

\section{KESIMPULAN}

RPP dibuat sesuai dengan langkah-langkah metode Discovery Learning dengan hasil perencanaan pelaksanaan pembelajaran yang disusun kerjasama antara peneliti dan guru kelas IV SDN 44 Kalumbuk Kec Kuranji Kota Padang. Hasil pengamatan RPP pada siklus I pertemuan 1 adalah 68\% dengan kualifikasi cukup, kemudian mengalami peningkatan pada siklus I pertemuan 2 dengan skor $85,71 \%$ mendapatkan kualifikasi baik. Nilai rata-rata yang diperoleh pada siklus I yaitu 76,79\% dengan kualifikasi baik. Sedangkan hasil pengamatan Rencana Pelaksanaan Pembelajaran (RPP) pada siklus II pertemuan 1 adalah 96\% dengan kualifikasi sangat baik. Perencanaan pada penelitian ini sudah termasuk kualifikasi sangat baik kerena berdasarkan hasil pengamatan RPP pada siklus I dengan skor $76,79 \%$ sudah mengalami peningkatan menjadi $96 \%$ pada siklus II.

Pelaksanan pembelajaran IPS dengan mengunakan metode Discovery Learning dapat 
diamati dari segi aspek guru and aspek siswa. Skor yang diperoleh untuk aspek guru pada siklus 1 adalah $80 \%$ dengan kualifikasi cukup mengalami peningkatan menjadi 95\% dengan kualifikasi sangat baik pada siklus II. Sedangkan skor yang diperoleh untuk aspek siswa pada siklus 1 adalah 75\% dengan kualifikasi cukup baik mengalami peningkatan menjadi $95 \%$ dengan kualifikasi sangat baik pada siklus II. Pelaksanaan pembelajaran IPS dengan menggunakan metode Discovery Learning sudah termasuk ke dalam kualifikasi sangat baik.

Penggunaan metode Discovery Learning dalam pembelajaran IPS di Kelas IV SDN 44 Kalumbuk Kec Kuranji Kota Padang dapat meningkatkan hasil keterampilan berpikir kreatif dan kritis. Hal ini dapat dilihat dari rekapitulasi penilaian hasil blajar siswa pada siklus II lebih tinggi jika dibandingkan dengan rekapitulasi hasil belajar siswa pada siklus I yaitu 75,89 dengan kualifikasi baik mengalami peningkatan menjadi 86,82 dengan kualifikasi sangat baik. Rekapitulasi hasil penilaian siswa pada siklus I juga sudah mengalami peningkatan pada siklus II karena siswa sudah banyak memperoleh nilai di atas kriteria ketuntasan minimum (KKM) yang sudah ditentukan.

\section{DAFTAR PUSTAKA}

Ahmed Soliman, S. (2019). Efficiency of an Edcational Robotic Compter-mediatd Training Program for Developing Stdents' Cretive Thiking Skills: An Experimental Study. Arab World English Journal, (5), 124140. https://doi.org/10.24093/awej/call5.10

Babic, T., Lackovic, A., \& Matejic, M. (2019). Critical Thinking and Creative Thinking - the self-assessment of Algebra University College students. 1, 843-848. https://doi.org/10.23919/mipro.2019.8757107

Hoicka, E., Mowat, R., Kirkwood, J., Kerr, T., Carberry, M., \& Bijvoet-van den Berg, S. (2016). OneYearOlds Think Creatively, Just Like Their Parents. Child Development, 87(4), 1099-1105. https://doi.org/10.1111/cdev.14431

Hosnan. 2014. Pendekatan Saintific and Kontekstual dalam Pemblajran Abad 21. Jakarta : Ghalia Indonesia.

Isjoni. 2007. Integrated Learning. Pekanbaru : Falah Production.

Jankowska, D. M., \& Karwowski, M. (2019). Family factors and development of creative thinking. Personality and Individual Differences, 142(July), 202-206. https://doi.org/10.1016/j.paid.2018.07.030

Majid. 2014. Pemblajran Tematik Terpadu. Bandung : PT. Remaja Rosdakarya.

Uno, Hamzah B. 2011. Menjadi Peneliti PTK yng Profesional. Jakarta : Bumi Aksara. 